\title{
The Effect of Aloe vera Gel on Widal Titer of Rats Ingested Salmonella typhi Bacteria
}

\author{
Renowati ${ }^{1}$, Enlita $^{2}$, Fitra Wahyuni ${ }^{3}$ \\ \{renowati01@yahoo.co.id ${ }^{1}$ \} \\ Medical laboratory technology department of Perintis Padang School of Health Science, Simp. \\ Kalumpang, LubukBuaya, Padang ${ }^{1,2}$ \\ Nursing department of Pekanbaru Medical Center School of Health Science, Lembaga \\ Permasyarakatan No. 25, Gobah Pekanbaru, Riau ${ }^{3}$
}

\begin{abstract}
Aloe vera was a traditional medicinal plant that can react as an adjuvant to increase the immune response to antigens because of that Aloe vera was called an immunomodulator. Salmonella typhi bacteria can be destroyed and eliminated by improving macrophage function. This can be done using immunostimulants that have a function as immunomodulators. One plant that acts as an immunostimulant is Aloe vera. The Widal test is one method that utilizes immunology to determine levels of antibodies in the serum, to help diagnose typhoid fever. Based on the description, a study was conducted to see the effect of Aloe vera gel on widal titer in rats that were ingested by Salmonella typhi. This study used white male rats (Rattusnorvegicus L.) strain Wistar, body weight 200 grams consisting of 4 groups with 2 treatments 7 times repetition, namely P1 (Aloe vera gel $1.8 \mathrm{ml} / 200 \mathrm{~g} / \mathrm{Bw}$ ), P2 (Aloe vera gel $3.6 \mathrm{ml} / 200 \mathrm{~g} / \mathrm{Bw}$ ), control (+) ingested Salmonella typhi bacteria and not using Aloe vera gel, (-) using distilled water. The collected data includes objectively tested data, namely Widal titers. The Mann Whitney test results showed that Aloe vera gel affected the decrease of tidal titer (antibodies) in white rats which had been indicated by Salmonella typhimurium bacteria $(\mathrm{P}<0.05)$.
\end{abstract}

Keywords: Aloe Vera Gel, Male White Rats, Salmonella, Widal Agglutination titres.

\section{Introduction}

Typhoid fever is an acute infection of the digestive tract caused by the bacteria Salmonella typhi [1]. Typhoid fever each year is estimated to reach 16 million cases in the world, while in Indonesia still a serious health problem with an average incidence of 650 cases per 100,000 population in Indonesia [2].

Salmonella is a rod-shaped, gram-negative bacteria, belonging to the family Enterobacteriaceae, has motile and pathogenic properties [3]. These bacteria have specific hosts and pathogens in humans including Salmonella typhi and paratyphi, while those that are pathogens in rats are Salmonella typhimurium, with pathogenicity similar to human typhoid fever. Therefore rats can be used as a model for experimental research on typhoid fever [4].

Infection Salmonella in animals is also common and is believed to be a major factor in transferring Salmonella to humans through the food chain. Salmonella typhi enters orally through contaminated food, then passes through the intestinal epithelium and Peyer's patches. This is where bacteria spread through the masricric lymph nodes and thoracic ducts, then 
circulate into the blood to the reticuloendothelial system such as liver, spleen and bone marrow. These bacteria can replicate and cause serious diseases. These bacteria can infect and survive in different types of cells, namely macrophages. and hepatocytes [5].

Bacteria Salmonella typhi can be destroyed and eliminated by improving macrophage function. Macrophages function as phagocytosis against these germs. This can be done using immunostimulants that function immunomodulators. One of the plants that act as immunostimulants is aloe vera [2].

Aloe vera is a traditional medicinal plant which can react as an adjuvant to enhance the immune response against the antigen. There is two modulator compounds in the gel of Aloe vera are distinguished functionally and chemicals that can inhibit the formation of antibodies because of that Aloe vera is called an immunomodulator [6]. One of the compounds in Aloe vera which can act as an immunomodulator is acemannan. Acemannan has a direct effect on immune system cells, activates and stimulates macrophages, monocytes, antibodies, and $\mathrm{T}$ cells. Other studies in mouse macrophage cells, acemannan can stimulate the production of macrophage cytokines. While studies in humans, acemannan was able to increase lymphocyte response against alleged to increase the release of IL-1 by monocytes [7].

Bashir et al. (2011)[8] found that Aloe vera gel can inhibit the growth of Gram-positive bacteria by $75.3 \%$ and was able to inhibit the growth of Gram-negative bacteria up to $100 \%$. Then Widia's (2012)[9] study also found that gel of Aloe vera effective for Gram-positive bacteria (Staphylococcus aureus, Staphylococcus epidermidis, Streptococcus pyogenes) and Gram-negative (Pseudomonas aeruginosa). The results of Rahayu's (2006)[10] research said that the extract of Aloe vera at a concentration of $10.5 \%$ was able to inhibit the growth of E. coli bacteria and Salmonella typhimurium with inhibitory zones of $7.9 \mathrm{~mm}$ and $6.5 \mathrm{~mm}$.

Early diagnosis of typhoid fever is needed so that the right treatment can be given immediately so that complications can be avoided [11]. Widal test is one method that utilizes immunology, to help diagnose typhoid fever in which the principle is based on the agglutination reaction between antigen Salmonella typhi and antibody (agglutinin) in serum. Widal test can be done by tube method or by slide method. To support the diagnosis of typhoid fever the reference threshold needs to be determined and the Widal test is considered positive if the antibody titers are $1 / 160$, both for agglutinin $\mathrm{O}$ and agglutinin $\mathrm{H}$ with a single or combined diagnostic criterion [11].

Based on the description, this study was conducted to see the effect of Aloe gel version on widal titer in rats that were ingested Salmonella typhi.

\section{Research Methods}

\subsection{The research phase}

This study will be carried out in four stages, namely the preparation of experimental animals, Aloe gel preparation, dosage planning, and treatment in experimental animals. Preparation of experimental animals was fabricating rats to the condition of laboratory atmosphere, weighing measurements of widal levels. Aloe gel preparation was manufactured of aloe gel solution, and dosage planning was based on the conversion dose, the human body weight was $70 \mathrm{~kg}$ and the conversion dose from humans was $200 \mathrm{grams} / \mathrm{kg} / \mathrm{BW}$. Treatment on experimental animals was the administration of aloe vera gel in rats which had been ingested Salmonella thypi. 


\subsubsection{Animal model preparation}

All rats that will be given the treatment are adapted for 7 days with their environment. During adaptation, rats are weighed at the beginning and the end of adaptation. Cages, places to eat and drink are cleaned at least three times a week, and the temperature and humidity of the room are considered. The amount of feed consumption per day is an average of $50 \mathrm{gr} / 200 \mathrm{gr} / \mathrm{Bw}$, water needs $8-11 \mathrm{ml} / 100 \mathrm{gr} / \mathrm{BW}$. Mice were divided into 4 groups, namely 1 negative group, 1 positive control group and 2 treatment groups, which were caged separately. Each group was treated according to a predetermined procedure.

\subsubsection{Aloe gel preparation}

Choose Aloe vera has is solid fleshy and leaves are light green. Cutting the upper and lower sides of the leaf, then transfer these Aloe gel from the leaves into the blender, puree [8], dividing it into 2 volumes for multilevel doses of $100 \mathrm{ml}$ and $200 \mathrm{ml}$, then each volume multiplied by 0.018 yields $1.8 \mathrm{ml} / 200 \mathrm{gr} / \mathrm{Bw}$ and $3.6 \mathrm{ml} / 200 \mathrm{gr} / \mathrm{Bw}$.

\subsubsection{The Dosage Planning}

The dosage of aloe versed in the study was calculated based on the use of aloe on humans. Based on the conversion dose, the human body weight was $70 \mathrm{~kg}$ and the conversion dose from humans was 200 grams that multiplied by 0.018 and the results obtained were $1.8 \mathrm{ml} / \mathrm{day}$, and $3.6 \mathrm{ml} / \mathrm{day}$ [12].

\subsubsection{Treatment in Animals}

28 white male rat Rattusnovergicus strain Wistar divided into 4 groups, namely: Negative Control Group: In this group rats were only given standard feed. Positive Control Group: In this group, rats were exposed to a suspension of Salmonella $10^{5} \mathrm{CFU} / \mathrm{ml}$ for 14 days and was not given gel of Aloe vera. Treatment Group 1: In this group, rats were exposed to a suspension of Salmonella $10^{5} \mathrm{CFU} / \mathrm{ml}$ for 14 days and given gel of Aloe vera with a dose of $1.8 \mathrm{ml} / 200 \mathrm{gr} / \mathrm{BW}$ for 7days. Examination of Widal titers was measured on the last day of the study. Treatment Group 2: In this group, rats were exposed to a suspension of Salmonella $10^{5} \mathrm{CFU} / \mathrm{ml}$ for 14 days and given gel of Aloe vera at a dose of $3.6 \mathrm{ml} / 200 \mathrm{gr} / \mathrm{BW}$ for 7 days. Examination of Widal titers was measured on the last day of the study.

\subsection{The Research Design}

This study was an experimental study with a post-test group design only design which was used to measure the effect of treatment on the experimental group by comparing the group with the control group. The sample consisted of 4 groups, namely 2 control groups (negative and positive) and 2 treatment groups. This study was conducted in January 2018 - October 2018, that carried out at the Perintis School of Pharmacy Laboratory. Independent variables in this study were male rats that had ingested bacteria Salmonella Typhi so that rats were infected with the treatment of aloe gel. The dependent variable was Widal titers in infected and not on male rats. 


\subsection{Data Collection Techniques}

Collected data includes objectively tested data, namely Widal levels in serum. Widal test is a reaction between agglutinin antibodies in the serum of rats that have undergone different dilutions of somatic antigen $(\mathrm{O})$ and flagella $(\mathrm{H})$ which are added in the same amount to cause agglutination. Visual measuring instrument Positive Measurement Results $=$ agglutination at levels $\geq 1 / 160$, Negative $=$ agglutination in titers $<1 / 160$ Scale Measuring Ratios.

\subsection{Data Analysis}

The data obtained were recorded, tabulated and statistically analyzed using a computer program with a 95\% confidence interval and significant level $0,05(\mathrm{p}<0.05)$. The data obtained were tested for normality with Shapiro-Wilk. Data is not normally distributed and homogeneous (p $<0.05)$ then followed by a non-parametric test that is to see the mean before and after. Then the Wilcoxon test was used to see the group differences after treatment, the test was used KruskalWallis with a $95 \%$ confidence level so that it could be seen whether the differences obtained were meaningful or not. The Kruskal-Wallis test will be considered significant if $p<0.05$ and then performed the test post hoc LSD (least significant difference) to see the difference between each treatment group using test the Mann-Whitney.

\section{Results}

\subsection{General Characteristics Subject Research}

This study concerning the influence of gel Aloe vera to Widal test to see the presence of antibodies in rat serum ingested Salmonella typhi, with a sample of 24 male white Wistar rats. The rats were grouped into 4 groups: negative control group (NC), positive control group (PC) and group 3 was treatment 1 (T1) given $1.6 \mathrm{ml}$ aloe gel, treatment group 2 (T2) was given 3.8 $\mathrm{ml}$ aloe gel. Each group consisted of 6 male Wistar white rats, the data used as the parameters of the study were widal test in male white rats (Rattusnovergicus).

\subsection{Normality Test}

The results of the normality test of the data in the Shapiro-Wilk test of Widal test was obtained for all study groups before and after giving the aloe gel was not all groups were normally distributed, thus to see the difference before and after, the Wilcoxon test was used and the difference after giving aloe gel between the study groups can be continued with the KruskalWalis test. 


\subsection{Difference in Average Widal Test Before and After Giving Aloe Vera}

Table 3.1 The differences in average widal titer before and after giving Aloe vera gel

\begin{tabular}{lllllr}
\hline \multirow{2}{*}{ Variable } & Mean \pm SD & \multirow{2}{*}{ N } & \multicolumn{2}{c}{ P } \\
\cline { 2 - 3 } & Before & After & & \multicolumn{2}{c}{ value } \\
\hline NC & - & - & 6 & 1.000 \\
PC & $373.3 \pm 130,6$ & $426.7 \pm 165.2$ & & 6 & 0.317 \\
T1 & $373.3 \pm 130.6$ & $106.7 \pm 41.3$ & 6 & 0.024 \\
T2 & $373.3 \pm 130.6$ & - & 6 & 0.020 \\
\hline
\end{tabular}

Based on table 3.1 above can be seen that all research groups only group treatment 1 (T1) and treatment group 2 (T2) which had significant differences between levels before and after giving aloe vera gel with a value of $\mathrm{p}<0.05$.

\subsection{Difference in Average Widal Tests After Giving Aloe Vera Between Various Study Groups}

Table 3.2 Differences in Average WidalTest Between Various Study Groups

\begin{tabular}{llll}
\hline Variables & $\begin{array}{l}\text { Widal test } \\
\text { (Mean } \pm \text { SD) }\end{array}$ & $\mathrm{n}$ & $\mathrm{p}$ \\
\hline $\mathrm{NC}$ & - & 6 & \\
$\mathrm{PC}$ & $426.7 \pm 165.2$ & 6 & 0.000 \\
$\mathrm{~T} 1$ & $106.7 \pm 41.3$ & 6 & \\
$\mathrm{~T} 2$ & - & 6 & \\
\hline
\end{tabular}

Based on table 3.2 it can be seen that the statistical test results obtained $p<0.05$, which means that at $5 \%$ alpha it can be concluded that there is a difference in the average widal test after giving aloe gel between the four groups of experimental mice. The Post Hoc test for the Widal test between research groups can be seen in Table 3.3 below.

Table 3.3 Widal Post Hoct Test Results after being given aloe vera gel between Group Treatment

\begin{tabular}{lllll}
\hline Groups & KN & KP & P1 & P2 \\
\hline NC & - & $\mathbf{0 . 0 0 2} *$ & 0.394 & 1,000 \\
PC & $\mathbf{0 . 0 0 2} *$ & - & $\mathbf{0 . 0 0 2} *$ & $\mathbf{0 . 0 0 2} *$ \\
T1 & 0.394 & $\mathbf{0 . 0 0 2} *$ & - & 0.394 \\
T2 & 1.000 & $\mathbf{0 . 0 0 2} *$ & 0.394 & - \\
\hline
\end{tabular}

From table 3.3 it can be seen that the group is significant there are differences are the negative control group (NC) with the positive control group (PC), the positive control group (PC) and the treatment group 1 (T1) and the positive control group (PC) with treatment group 2 (T2). 


\section{Discussion}

Widal titer results before being given aloe vera gel in the negative control group (NC) were negative, positive control group (PC) was $373.3 \pm \mathrm{SD}$, treatment group 1 (T1) was $373.3 \pm \mathrm{SD}$, treatment group 2 (T2) The results showed that the group that had a positive result was the PC group, T1 and T2, It is because in this study the group given the Salmonella typhi bacteria was indeed expected to experience typhoid fever infection.

The rats used in this study were rats which were declared infected with Salmonella typhi bacteria with positive Widal test results, infected rats by inducing Salmonella typhi $10^{5} \mathrm{CFU} /$ $\mathrm{ml}$ into the rat's body orally. The induction of Salmonella typhimurium $10^{5} \mathrm{CFU} / \mathrm{ml}$ succeeded in making typhoid in rats (Rattusnovergicus male Wistar) after an incubation period of 14 days. Salmonella typhimurium bacteria which were indicated (orally) in the small intestine, bacteria invade small intestinal lymphoid tissue (especially payer plaque) and mesenteric lymphoid tissue. After causing local inflammation and necrosis of germs through the lymphatic vessels into the blood (primary bacteremia) to the organs, reticuloendothelial system (RES) especially the liver and spleen. In this place, germs are phagocytes by RES phagocytes and germs that are not phagocytes will multiply [13].

At the end of the incubation period, ranging from 5-9 days, the germs return to blood to spread throughout the body (secondary bacteremia), and some germs enter the body's organs, especially lymphatic, gallbladder, which in turn is released from the gallbladder into the intestinal cavity and causes infected with intestines. During this bacteremia, the germ secretes endotoxin whose chemical composition is the same as that of somatic antigen (lipopolysaccharide), which was originally thought to be responsible for the occurrence of symptoms of typhoid fever [13].

In this study, the Aloe vera used as a gel. The gel is a slimy part obtained by slicing the inside of the leaf after the exudate is removed. This gel contains rich nutrient values [14] and has an antibacterial, antiviral, anti-fungal and anti-inflammatory effect. The gel is given to ticks which have been infected with salmonella typhimurium bacteria and observed for one week.

Giving Aloe vera gel for 7 days can reduce the number of antibodies found in mouse serum. At a dose of $1.8 \mathrm{ml}$ for 7 days reduced antibody levels from 373.3 \pm SD to $106.7 \pm \mathrm{SD}$ and giving aloe vera gel at $3.6 \mathrm{ml}$ per day was able to reduce antibody levels from 373.3 to negative. Based on the results of the study [8] found that aloe vera gel was able to inhibit the growth of Gram-positive bacteria by $75.3 \%$ and was able to inhibit the growth of Gram-negative bacteria up to $100 \%$. Then [9] study also found that gel Aloe vera effective for Gram-positive bacteria (Staphylococcus aureus, Staphylococcus epidermidis, Streptococcus pyogenes) and Gram-negative (Pseudomonas aeruginosa). The results of [10] research extract Aloe vera on at a concentration of $10.5 \%$ were able to inhibit the growth of E. coli bacteria and Salmonella typhimurium with inhibitory zones of $7.9 \mathrm{~mm}$ and $6.5 \mathrm{~mm}$.

The difference in the average Widal test between groups in the statistical test obtained $\mathrm{p}$ $<0.05$ in the test Mann-Whitney which means that at $5 \%$ alpha it can be concluded that there is a difference in the average widal test after giving aloe vera gel between the four groups of experimental mice. 


\section{Conclusion}

The average Widal test results before being given aloe vera gel were $373.3 \pm \mathrm{SD}$ at PC, T1, T2. The average result of Widal test after giving aloe vera gel was $426.7 \pm \mathrm{SD}$ in PC, $106.7 \pm$ $\mathrm{SD}$ at $\mathrm{T} 1, \mathrm{~T} 2$. There is a difference in the rat Widal serum test average before and after treatment in the group given Aloe Vera gel, namely treatment group 1 (T1) and treatment group 2 (T2). There is a difference in the Widal test average before and after giving aloe vera gel to various groups which means there is the effect of aloe vera gel on the presence of antibodies of mice infected with Salmonella typhimurium.

\section{References}

[1] Widoyono.: Tropical Diseases. Publisher Erlangga.(2011)

[2] Susanti, R.:Reactive Oxygen Species Activity Due to Stimulation of Aloe Vera Gel on Astralellatyphimurium Infection, MIPA35 Journal (1), 2.(2012)

[3] LB Hawley: Digest of Microbiology and Infectious Diseases, Translation of Pendit BU, HippocratesPublisher : Jakarta (2003)

[4] Dewi, H.: The Effect of Giving Aloe Vera Extract on Lymphocyte Proliferation in Lien in MiceBalb / c injected by Salonellatyphimurium, Thesis of Diponegoro University: Semarang (2007)

[5] Nasronudin: Typhoid Fever in Infectious Diseases in Indonesia, Airlangga University Press, p: 121-125. (2007)

[6] Davis, RH: Polysaccharide in Aloe vera the magic bullet. URL: http://www.wholeleaf.com (2007)

[7] Saputra, K., Maat, S., Soedoko, R., Biological therapy for cancer. Surabaya: Airlangga University Press: 58-60.(2000)

[8] Bashir, A. Saeed, B., Mujahid, TY, Jehan, N.: Comparative Study of Antimicrobial Activities of Aloe vera Extracts and Antibiotics Against isolates From SkinInfections,African Journal of Biotechnology, 10 (19), 3835-3840.(2011)

[9] Widia, W.: Formulation of Preparation of Ethanol Extract of Aloe Vera (L.) Webb) Aloe Vera Extract as an Anti Acne with Sodium Alginate Base and Antibacterial Activity on Staphylococcus epidermidis, Publication Manuscript: Surakarta.(2012)

[10] Rahayu, ID: Aloe barbadensis Miller and Aloe Chinensis Baker As Antibiotic In Medication of Poultry Ethnoveteriner By In Vitro, Journal of Protein, 13 (1), 31-34. (2006)

[11] Wardhani, Puspa.,Prihatini ., Probohoesodo, MY: Widal Tube Test Ability Using Imported Antigen and Local Antigen, Indonesian Journal of Clinical Pathology and Medical Laboratory, Vol. 12, No. 1.(2005)

[12] Kusumawati, D: Friendly with Animal Try, Gajah Mada University press: Yogyakarta .(2004)

[13] Rampengan, TH, Tropical infections in children. Jakarta: EGC.(2007)

[14] Idris, M.,:Effectiveness of Aloe vera Extract on Streptococcus sanguis Bacteria Growth, Thesis of Hasanudin University: Makassar (2013) 